\title{
A Self-Fulfilling Dystopia
}

\author{
Daniel Chernilo
}

Published online: 24 May 2011

(C) Springer Science+Business Media, LLC 2011

To the extent that reductionism has never made for good social science, I do not think that it is enough to suggest, as Richard Sennett (2011) has recently argued, that the story around the London School of Economics' reception of a donation from the Gaddafi family 'is all about cash'. In society, things are never so simple and it is in the very call of our disciplines that we ought to actively search for what else may have actually been going on. I should then like to use this short intervention as an opportunity to reflect on some broader normative and epistemological questions that I think are important to understand how recent engagements between academic institutions, social scientists, and regimes with dubious normative credentials could have been found acceptable in the first instance.

To be sure, these kind of engagements with tyrants and their regimes are far from new; take, for instance, the relationships between Milton Friedman and fellow economists in Chicago and the Pinochet dictatorship. But current cases may have been additionally triggered by a widespread view in the social sciences that the social world itself is fully devoid of any sense of normativity. Recent trends in our disciplines have decidedly contributed to a conceptualisation of the social world as populated by actors whose only concern is the defence of their identities and the advancement of their material interests. And the more important the promotion of one's own interest becomes, the less the space for normativity in society. We have then ended up with the self-fulfilling dystopia of a social world with no place or role for the normative.

D. Chernilo $(\bowtie)$

Department of Social Sciences, Loughborough University, Loughborough LE11 3TU, UK

e-mail: D.Chernilo@lboro.ac.uk
I will take sociology as my case study and proceed in three steps:

(1) Sociology has not yet fully come to terms with the combined effects of the postmodern (gender, culturalist, postcolonial) and globalist critiques of the past few decades. While their role was crucial in trimming down reified presuppositions and unwarranted generalisations of earlier sociology, a more problematic and less noticed consequence of this double-blow has been that their ultimate depiction of 'the social' is one in which there is no space for serious normative considerations inside the social world itself.

(2) Not only social scientific concepts but also the social world itself becomes a space with no normativity. While this can and has been presented as an advancement of the discipline's scientific maturity, it also creates a severe void in our understanding of social relations. This inability to grasp the role of the normative in social life dramatically backfires when the discipline itself is called to reflect on trends and events in which the most challenging questions refer precisely to those normative dimensions that are no longer conceived as a real aspect of the social world.

(3) Yet the attempt to recover a sense of normativity under current conditions of global modernity comes at a price: it requires us to re-engage with the universalistic thrust that actually underpins some of the very ideas and ideals that this affair have brought into question: the extent to which such issues as democracy, freedom or human dignity have really become a common property of humanity. Several difficulties and challenges follow from this, of course - not least, whether this can be done without resorting back to precisely 
the unwarranted generalisations that led to postmodern and globalist critiques in the first place.

1. Arguably, the debates on postmodernity and globalization that have marked the social sciences over the past four decades or so have had in common a radicalization of modernity's key proposition that 'all that is solid melts into air'. Although postmodernism's claim on the end-of-everything and globalization's opposite argument on the novelty-of-everything mirror each other in their excesses, their criticisms are compatible to the extent that their main target was what we now can refer to as a 'first generation' Euro- or Westerncentrism. To be sure, a number of criticisms were well made back then and, to that extent at least, some important lessons can be said to have been learnt: we are now more modest in asserting the ability of our theories and methods to warrant worldwide generalisations, have expanded the array of what counts as relevant or adequate empirical evidence, give increasingly 'reflexive' accounts of our standpoints vis-à-vis our immediate social context, and accept that there is no one-sizefits all theory of modernity. These are of course developments to be welcome.

But when called to interpret trends and events in which fundamental normative considerations are crucially at stake, another much more problematic consequence of this double-blow also begins to emerge: our disciplines' normative sensibility - their moral texture (Nisbet 1967) - shows signs of dramatic erosion. Somewhat paradoxically, through explicitly antipositivistic arguments postmodernism and globalism achieved precisely one key goal that the century-old positivistic agenda was never fully able to accomplish: a sense that our disciplines are in fact ill-equipped to understand, let alone advance or criticise, substantive normative questions. But the current situation goes beyond positivism's wildest dreams: while positivism was mostly about arguing that normative challenges were ultimately alien to the purposes of social scientific research, the result of this double blow is the ontological amplification of positivism: 'the social' itself has been emptied of its normative dimension (Luhmann 1995).

The paradigmatic status of Pierre Bourdieu's (1990) sociology may serve to illustrate my point further. Committed as it is to advocacy, Bourdieu surely engages with normative questions. But the way in which normativity is there conceptualised precludes rather than allows its inclusion as a relevant dimension in the social world. Bourdieu's sociological advocacy is organised around the fact that certain social actors need to be defended against other more powerful ones. The role of the sociologist becomes then that of a 'reflexive amplifier' with the help of which the voices of these subordinate actors may get heard and their interests strategically advanced wherever and whenever it matters. However sophisticated and well-meaning, Bourdieu's sociology does not have a space for the normative in society: what is ultimately at stake is that the interest of vulnerable actors be promoted. While I am actually in favour of the politics of advocacy, I do worry that it reinforces this view of social relations as fully devoid of normative content. His portrayal of the social world is one that is populated exclusively by strategic actors for whom competition is the only game in town

A major consequence of this reductionist view is that careful consideration of what is normatively at stake, and why the normative is important for actors themselves, is replaced by the empirical question of the actor's bargaining position vis-à-vis others. As events in the social world are ultimately about promoting one's interests, what actors stand for matter way less than the defence of their interests. We ought to challenge the Hobbesian philosophical anthropology that underpins this understanding of the social world: social actors do not consider themselves as purely strategic beings, they also need and actively search for normative justifications.

2. While it is the empirical diagnosis of modern society's increasing complexity and pluralisation that led to the idea that normativity was no longer necessary to comprehend the social world, we might as well see it as a kind of self-fulfilling prophecy: to the extent that recent ontologies of the social have no space for the normative, it is of little surprise that we find it increasingly difficult to include normative questions and challenges as a relevant part of what we do as social scientists. A critical expression of this trend, it seems to me, can be found in the often heard claim that we live at a critical historical crossroad in which previous intellectual parameters decline without newer ones having come to replace the older ones. That the social world is rapidly changing should come as no surprise to any social analyst. But it is when coupled with the idea of a social world with no normativity that our runaway world finally runs away. The space is now created for justifying our changing allegiances because one's own interests thus require it: there is nothing to worry about, this just what actors do in society.

In relation to the events that directly concern us here, this may help explicate the problems of the 'hindsight argument' - that errors in judgements were such only because we did not know then what we now know. 
Take Anthony Giddens' (2007) decision to speak publicly in favour of giving Colonel Gaddafi 'another chance' a few years ago: the Libyan dictator had already been 35 years in power and the human rights record of his regime was already well known. In fact, it is Giddens' argument in that piece the one that is based on hindsight, as his defence of Gaddafi depends on him knowing about the colonel's own transformed intentions: Giddens acknowledged that Gaddafi had been a bad guy but it was after talking to him that he now knew that the lessons had been learnt by the colonel.

A further expression of this reductionist vision of the social world is found in the rise of what we may call a 'second generation' of Eurocentric arguments. Over a decade ago, Ulrich Beck sought to analyse recent socioeconomic reforms in Germany by borrowing from Shalini Randeria the idea of 'the Brazilinization of the West'. Although Beck was aware that 'such an emphatic image may arouse suspicions of a reverse Eurocentrism', he decided to use it nonetheless: 'in a striking reversal, countries of so-called "premodernity", with their high proportion of informal, multi-activity work, may reflect back the future of the so-called "late-modern" countries of the Western core' (Beck 2000: 93). While this may arguably differ from the normative emphasis of previous Eurocentrism, it still fails to look at the rest of the world in its own merits, as a full and equal partner of our global modernity, rather than in terms of what it says about 'the West'. In similar fashion, Giddens (2007) spoke of his hopes that Libya could one day become 'the Norway of Africa': bad habits do die hard (Archer 1991). As with all forms of Eurocentrism, the problem here is that all actors involved are reified. On the one hand, non-Western peoples are not accorded any sense of agency and whatever they may be able to achieve will still have to be assessed against the external and indeed 'higher' standards of the West. On the other hand, it also expresses a failure by 'old and respectable' nation-states to accept the distance between their own idealised selfpresentations and the rather brutish nature of their real practices both 'at home' (class and gender discrimination) and 'overseas' (racism and imperialism). No idea of the normative is allowed within a social world thus conceived.

3. Normative considerations were not really central when decisions to engage with the Gaddafi's regime were being made. Let's remember that taking his donations and accepting his hospitality were all things being done openly and, while not everyone was in favour of them (Halliday 2011), these decisions were made in accordance with the internal procedures of the LSE's governing bodies. It is not that they could be accepted, they had to be accepted because this is what corporate actors do when in situations of negotiation: a deal is closed when all parties directly involved become satisfied with the terms of the arrangement. But at a time when the public vocation of universities is being questioned worldwide, and when the ability of the social sciences to make a difference in the world is being challenged, what is being publicly demanded from our disciplines is that we humbly but decidedly face the tensions between facts and norms (Habermas 1996): humbly, as old self-righteousness carries no weight these days; decidedly, as the big issues of democracy, human dignity, freedom, poverty or justice can only be meaningfully addressed when their normative dimension is seriously taken into account.

But these are issues that can only be discussed and reflected upon if we are prepared to acknowledge that there is a strong universalistic orientation built into them - and that that is precisely the reason why they matter so much. And yet universalism has become a non-starter in much of contemporary social science. Of all the charges being raised against it, let me address here the one that maintains that it is never really universal but always a hypostatised generalisation of the Western particular. Whether this is empirically true can and possibly ought to be questioned (Voegelin 2000), but the weight this criticism carries is not dependent upon historical origins. Rather, it presupposes a social world with no normativity: universalism becomes only a strategy certain actors deploy to promote their interests because that is all that actors do in the social world. As soon as we allow the normative back into the social world, however, a new account can begin to emerge. We can reassess modernity's truly original universalistic aspirations because we need to come to terms, simultaneously, with its global expansion and the decline of its Eurocentric matrix.

The way forward is trying to comprehend those trends and events that mark the truly worldwide condition of current modernity without, in the same move, continue advancing unsound generalizations from the West to the rest. We need to rethink universalism sociologically as a claim that it is inescapable to the actual worldwide condition of modernity, fallible as it remains always open to better or more abstracts ways of grounding it and nonEurocentric with regards to cross-cultural comparisons and normative assessments.

If we accept that the Arab revolutions of early 2011 are about democracy - how are we to explain them? Unless we want to argue that getting rid of tyrants is not 
something worth fighting for, three options remain. First, we can reduce these revolutions to yet another expression of Western imperialism. Second, that these populations want 'Western' democracy because democracy is a Western value: these revolutions are a proof of the West's success in having promoted their particular aspirations and way of life the world over. Third, we can see them as a quest for democracy because such values as justice, freedom and equality are appealing as universal human experiences. As the first two would still be an expression of both the Eurocentric views of social relations that we ought to leave behind, only the latter, it seems to me, is a plausible explanation.

My argument here may be seen as a variation of the foundational Weberian problem of value-neutral social sciences: what can we say in our expert capacity about value decisions? But whereas for Weber the challenge was that our disciplines could not save us from having to decide what ought to be done because the social world was populated by too many value orientations, the diagnosis now is that there are no values left in the social world. Accepting the intrinsic difficulty of normative challenges and then calling for personal responsibility is altogether different from strategically seeking for normative reasons to defend whatever is good for us. The latter becomes increasingly possible because of the distorted sense of normativity with which some contemporary social scientists have been conceptualising the social world. The damage to our disciplines' reputation is not beyond repair. But their future credibility may depend on our ability to change course and practice a non-moralising yet normatively attuned social science.

\section{Further Reading}

Archer, M. 1991. Sociology for one world: Unity and diversity. International Sociology, 6(2), 131.

Beck, U. 2000. The brave new world of work. Cambridge: Polity.

Bourdieu, P. 1990. The logic of practice. Cambridge: Polity.

Giddens, A. 2007. My chat with the colonel. http://www.guardian.co. uk/commentisfree/2007/mar/09/comment.libya. Last access 4 March 2011.

Habermas, J. 1996. Between facts and norms. Massachusetts: MIT Press.

Halliday, F. 2011. Memorandum to the London School of Economics Council warning it not to accept a grant from the Gaddafi Foundation. http://www.opendemocracy.net/fred-halliday/memorandum-to-lsecouncil-on-accepting-grant-from-qaddafi-foundation. Last access 17 March 2011.

Luhmann, N. 1995. Social systems. Stanford: Stanford University Press.

Nisbet, R. 1967. The sociological tradition. London: Heinemann.

Sennett, R. 2011. Universities need your Titians. http://www.guardian. co.uk/commentisfree/2011/mar/06/universities-titian-lse-dodgydonors. Last access 9 March 2011.

Voegelin, E. 2000. The ecumenic age. In M. Franz (Ed.), The collected works of Eric Voegelin (Vol. 17). Columbia: University of Missouri Press.

Daniel Chernilo is Senior Lecturer in Sociology at Loughborough University. He is the author of A Social Theory of the Nation-State (Routledge, 2007) and his forthcoming monograph on natural law, universalism and modern social theory will be published by Cambridge University Press. 